\title{
Pharmacognostical and Pharmaceutical analysis of Gandhakadi yoga vati
}

\author{
Research Article
}

\author{
Kalawana OTMRKSB ${ }^{1^{*}}$, Harisha $\mathrm{CR}^{2}$, Patel $\mathrm{KS}^{3}$, Kori $\mathrm{VK}^{4}$, Rajagopala $\mathrm{S}^{5}$ \\ 1. PG Scholar, 3. Professor and HOD, 4. Assistant Professor, 5. Associate Professor, Dept. of Kaumarbhritya \\ 2. Head, Pharmacognosy Laboratory \\ I.P.G.T.\&R.A., Gujarat A yurved University, Jamnagar, Gujarat, India.361008
}

\begin{abstract}
Ayurveda is one of the oldest medical systems having its own strong scientific concepts. Most herbal, Animal and mineral products are used to make Ayurvedic formulations and ancient Ayurvedic Aachaaryas have mentioned various methods to quality control and to standardization those formulations. And also it has been developed different techniques to evaluate the quality of medicines by modern science. So there is a current need of analyze Ayurvedic products also according to modern scientific pharmaceutical and pharmacognostical parameters for the global acceptance of Ayurveda. Hence the present study was carried out to pharmacognosticaly analyze the ingredients and finished product of Gandhakadi Yoga Vati and to analyze the Physico-chemical parameters of the same. Gandhakadi Yoga Vati is an Ayurvedic formulation used as an adjuvant in the management of Thalassemia Major. Pharmacognostical characteristics of Gandhakadi Yoga Vati under the microscope showed that oil globules, stone cells \& oleoresin contents, of Vidanga (Embelia robusta Burm.f.), fibers and oil globules of Agastya Pathra (S. grandiflora Linn.), warty trichome with base of Bhringaraja (E.alba L.) and crystaline depositions of Gandhaka. In the pharmaceutical study, it was observed that Loss on drying was $3.5 \% \mathrm{w} / \mathrm{w}$, $\mathrm{pH}$ was 6.5 , Alcohol soluble extractive was $8.9 \% \mathrm{w} / \mathrm{w}$ and water soluble extractive was $5.5 \% \mathrm{w} / \mathrm{w}$. HPTLC study showed 06 peaks at $254 \mathrm{~nm}$ and 03 peaks at $366 \mathrm{~nm}$ wave lengths.
\end{abstract}

Keywords: Gandhakadi Yoga Vati, Pharmaceutical analysis, Pharmacognostcal analysis

\section{Introduction}

Ayurveda is one of the oldest medical system having its own strong scientific concepts and being practiced by a large population in India as well as many countries. Most herbal, Animal and mineral products are used to make Ayurvedic formulations and ancient Ayurvedic Aachaaryas have mentioned various methods to quality control and to standardization those formulations according to the final dosage form.

The expected therapeutic effect from an administered drug can be got only if the quality of the finished formulation is in standard level. Quality of the finished drug is entirely depends on the quality and genuine of the raw materials. Therefore proper identification of raw material is a must as there are some controversies, adulteration and substitution regarding raw materials which has been described in Ayurvedic authentic literature. Hence the Pharmacognosy is one of the most important sciences in present Ayurvedic medical practice. Furthermore it has been developed different techniques to evaluate the quality of medicines with perspectives of safety,

\section{*Corresponding Author:}

Kalawana OTMRKSB

PG scholar, Dept. of Kaumarbhritya,

IPGT\&RA, Gujarat Ayurved University,

Jamnagar -361008.

E-mail: dr.senanikalawana@gmail.com efficacy and quality by modern science. Hence there is a need to analyze Ayurvedic products and draw out results according to modern scientific pharmaceutical and pharmacognostical parameters for the global acceptance of Ayurveda. In the present study pharmacognostical and pharmaceutical analysis were done in order to ensure the quality standards of the Gandhakadi Yoga Vati such as identity, quality, and purity of ingredients and finished product along with preliminary physico-chemical and pharmaceutical parameters and pharmacognostical characteristics(1).

\section{Materials and Methods \\ Ingredients of Gandhakadi Yoga Vati}

Table 1 - Ingredients of Gandhakadi Yoga Vati

\begin{tabular}{|l|l|l|l|l|}
\hline $\begin{array}{l}\text { N } \\
.\end{array}$ & Drug Name & $\begin{array}{l}\text { English / Latin } \\
\text { Name }\end{array}$ & $\begin{array}{l}\text { Part } \\
\text { Used }\end{array}$ & Quantity \\
\hline 1 & Shuddha & Sulphur & $\begin{array}{l}\text { As } \\
\text { whole }\end{array}$ & 1 part \\
\hline 2 & Vidanga & Embelia robusta & Dry & 1 part \\
\hline 3 & Agastya & $\begin{array}{l}\text { Sesbenia } \\
\text { grandiflora } \text { Linn. }\end{array}$ & $\begin{array}{l}\text { Green } \\
\text { Leaves }\end{array}$ & $\begin{array}{l}\text { As } \\
\text { sufficient }\end{array}$ \\
\hline 4 & $\begin{array}{l}\text { Bhringaraaja } \\
\text { (for gandhaka } \\
\text { Shodhana) }\end{array}$ & $\begin{array}{l}\text { Eclipta alba } \text { (L.) } \\
\text { Hassk. (syn. } \\
\text { Eclipta prostrata } \\
\text { L.) }\end{array}$ & $\begin{array}{l}\text { Green } \\
\text { Leaves }\end{array}$ & $\begin{array}{l}\text { As } \\
\text { sufficient }\end{array}$ \\
\hline
\end{tabular}


Collection, identification and authentication of raw drugs:

Raw Gandhaka (Natural Sulphur), dried fruits of Vidanga (Embelia robusta Burm.f.) and Panchanga (Whole plant) of fresh Bhringaraja (Eclipta alba L.) were supplied by the Pharmacy of Gujarat Ayurved University, Jamnagar and Fresh Agastya (Sesbenia grandiflora Linn.) leaves were purchased from the market.

All the drugs were authenticated for quality and purity by the experts of Pharmacognosy Laboratory of the Gujarat Ayurved University.

\section{Preparation of Gandhakadi Yoga Vati}

Gandhakadi Yoga Vati were prepared by following Standard Operating Procedures (S.O.P.) of preparation of $V a t i$ as practiced in the pharmacy, G.A.U., Jamnagar.

\section{Pharmacognostical study of Gandhakadi Yoga Vati}

Pharmacognostical analysis of the dry powders of ingredients and finished product of Gandhakadi Yoga Vati was carried out in the Pharmacognosy laboratory of I.P.G.T. \& R.A., G.A.U., Jamnagar.

\section{Organoleptic Characteristics}

Following Organoleptic Characters of Gandhakadi Yoga Vati were analyzed with the help of Darshana, Sparshana, Aaghrana and Rasana Pareeksha mentioned in Ayurveda. (By sensory observations). Results were mentioned in the Table no. 2 .

- Color

- Touch

- Odor

- Taste

\section{Microscopic Characteristics}

2 Vati of Gandhakadi Yoga were crushed and small quantity from this powder was dissolved in distilled water. Few drops of this is spread on a glass slide and covered with a cover slip and excessive water was removed with filter paper. Microscopic examination was done with the prepared slide first without staining and then stained with Fluroglucinol and concentrated $\mathrm{HCl}$ under Carl-zeiss Trinocular microscope. Photomicrographs were taken by using Carl-Zeiss Trinocular research microscope attached with camera. (2)

The Ayurvedic Pharmacopoeia of India (A.P.I.) standards were used for authentication.(3)

The microphotographs of the Pharmacognostical characteristics of Gandhakadi Yoga Vati are displayed in Plate1.

\section{Pharmaceutical study of Gandhakadi Yoga Vati}

Physico-chemical analysis of the finished product of Gandhakadi Yoga Vati was carried out in the Pharmaceutical laboratory of I.P.G.T. \& R.A., G.A.U., Jamnagar, on following parameters.
A. Physical tests:

Following Physical parameters of Gandhakadi Yoga vati were analyzed and results were mentioned in the table no. 3 .
Shape
Hardness (4)
Uniformity of weight (5)

Physico-chemical analysis:

Following Physico-chemical parameters of Gandhakadi Yoga Vati were analyzed and results were mentioned in the table no. 4.

$$
\begin{aligned}
& \text { Loss on drying (LOD) (6) } \\
& \text { Ash value (7) } \\
& \text { Acid insoluble ash value (8) } \\
& \text { pH Value (9) } \\
& \text { Water Soluble Extractive (10) } \\
& \text { Alcohol Soluble Extractive (11) }
\end{aligned}
$$

\section{High Performance Thin Layer Chromatography (HPTLC): \\ HPTLC was carried out after making appropriate} solvent system with Methanolic extract of Gandhakadi Yoga Vati. On performing HPTLC, visual observation under UV light showed few spots but on analyzing under densitometer at $254 \mathrm{~nm}$ and $366 \mathrm{~nm}$ it resulted into 6 and 3 spots respectively. Results of HPTLC are given in Table 5 and densitogram is shown in plate 2.

\section{Observations and Results Pharmacognostical study of Gandhakadi Yoga Vati}

\section{A. Organoleptic characters:}

Characters like color, odour, taste and touch of Gandhakadi Yoga Vati are mentioned in the table no. 1.

Table 2: Organoleptic characteristics of Gandhakadi YogaVati :

\begin{tabular}{|l|l|l|}
\hline $\begin{array}{l}\text { Sr. } \\
\text { No. }\end{array}$ & Parameters & Observations \\
\hline 1. & Color & Ash \\
\hline $\mathbf{2 .}$ & Touch & Smooth, Hard \\
\hline $\mathbf{3 .}$ & Odor & Pungent \\
\hline 4. & Taste & $\begin{array}{l}\text { Tasteless and ends with } \\
\text { Kashaaya Rasa }\end{array}$ \\
\hline
\end{tabular}

\section{B. Microscopic characters:}

Pharmacognostical characteristics of Gandhakadi Yoga Vati under the microscope showed that Oil globules, stone cells, Oleoresin contents, and Epicarp cells of Vidanga (Embelia robusta Burm.f.), Fibers and Oil globules of Agastya Pathra ( $S$. grandiflora Linn.), Parenchyma cells and Warty trichome with base of Bhringaraja (E.alba L.)and Crystaline depositions of Gandhaka were observed. The microphotographs of the same are displayed in Plate1. 
Plate 1: Microphotographs of Gandhakadi Yoga Vati

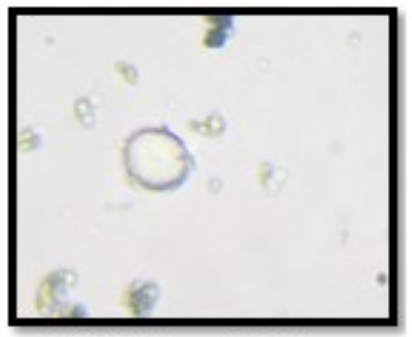

Oil globules of Vidanga

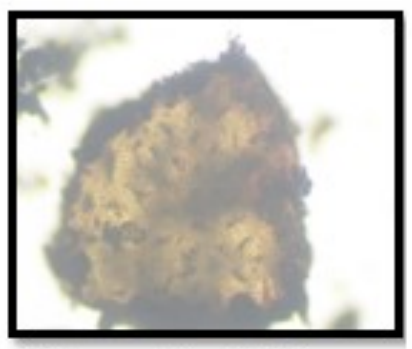

Epicarp cells of Vidanga

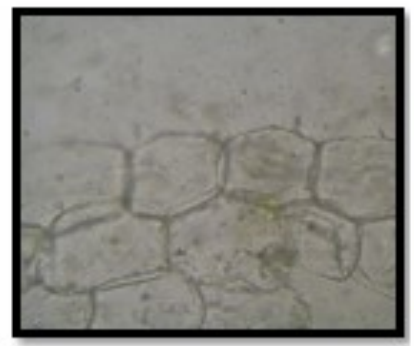

Parenchyma cells of Bhringaraja

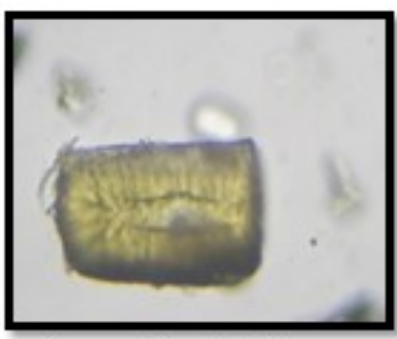

Stone cells of_Vidanga

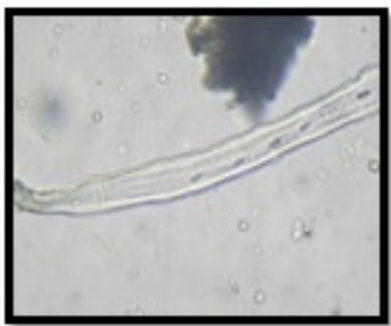

Fibers of Agasthya Pathra

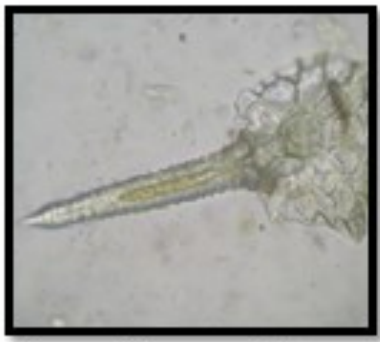

Warty trichome with base of Bhringaraja

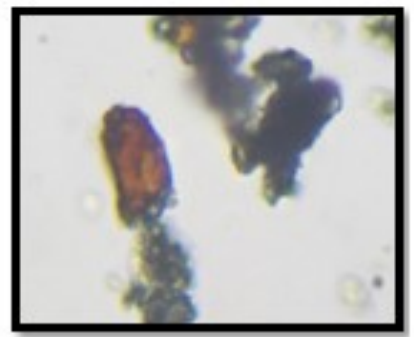

Oleoresins contents of Vidanga

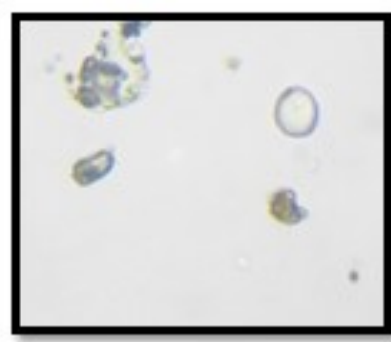

Oil globules of Agasthya Pathra

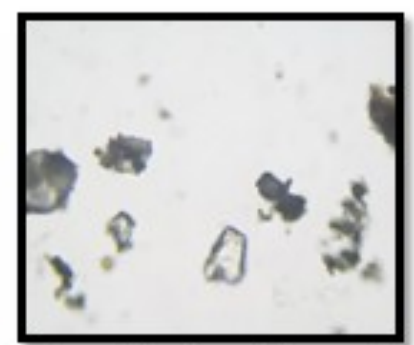

Crystaline depositions of Gandhaka

Pharmaceutical study of Gandhakadi Yoga Vati

Table 3: physical analysis of Gandhakadi Yoga Vati

\begin{tabular}{|c|c|c|c|}
\hline Sr. No. & \multicolumn{2}{|l|}{ Parameters } & Results \\
\hline & \multicolumn{2}{|l|}{ Shape } & round \\
\hline & \multicolumn{2}{|l|}{ Hardness } & $1.75 \mathrm{~kg} / \mathrm{cm}^{3}$ \\
\hline & \multirow{3}{*}{ Uniformity of weight } & Max. (mg) wt. & $644 \mathrm{mg}$ \\
\hline & & Min. (mg) wt. & $410 \mathrm{mg}$ \\
\hline & & Avg. (mg) wt. & $531 \mathrm{mg}$ \\
\hline
\end{tabular}

Table 4: Physico-chemical analysis of Gandhakadi Yoga Vati

\begin{tabular}{|l|l|l|}
\hline Sr. No. & \multicolumn{1}{|c|}{ Parameters } & Results \\
\hline 1. & Loss on drying at $110^{\circ} \mathrm{C}$ & $3.5 \% \mathrm{w} / \mathrm{w}$ \\
\hline $\mathbf{2 .}$ & pH of $5 \%$ aqueous solution & 6.5 \\
\hline $\mathbf{3 .}$ & Water soluble extractive & $5.5 \% \mathrm{w} / \mathrm{w}$ \\
\hline $\mathbf{4 .}$ & Alcohol soluble extractive & $8.9 \% \mathrm{w} / \mathrm{w}$ \\
\hline $\mathbf{5 .}$ & Ash Value & $0.277 \mathrm{~g}$ \\
\hline $\mathbf{6 .}$ & Acid insoluble Ash & $4.78 \%$ \\
\hline
\end{tabular}


Table 5: results of HPTLC of Gandhakadi Yoga Vati

Solvent system - Toluene : Ethyl acetate : Acetic Acid (7:2:1)

\begin{tabular}{|l|l|l|}
\hline $\begin{array}{l}\text { Wave } \\
\text { lengths }\end{array}$ & Short UV $(254 \mathrm{~nm})$ & Long UV $(366 \mathrm{~nm})$ \\
\hline $\begin{array}{l}\text { No of } \\
\text { Spots }\end{array}$ & $\mathbf{0 6}$ & $\mathbf{0 3}$ \\
\hline $\begin{array}{l}\text { Max. Rf } \\
\text { Value }\end{array}$ & $\mathbf{0 . 2 9 , 0 . 3 5 , 0 . 3 7 , 0 . 7 9 , 0 . 8 7 , 0 . 9 6}$ & $\mathbf{0 . 3 0 , 0 . 3 7 , 0 . 7 6}$ \\
\hline
\end{tabular}

Plate 2: Densitogram of HPTLC of Gandhakadi Yoga Vati

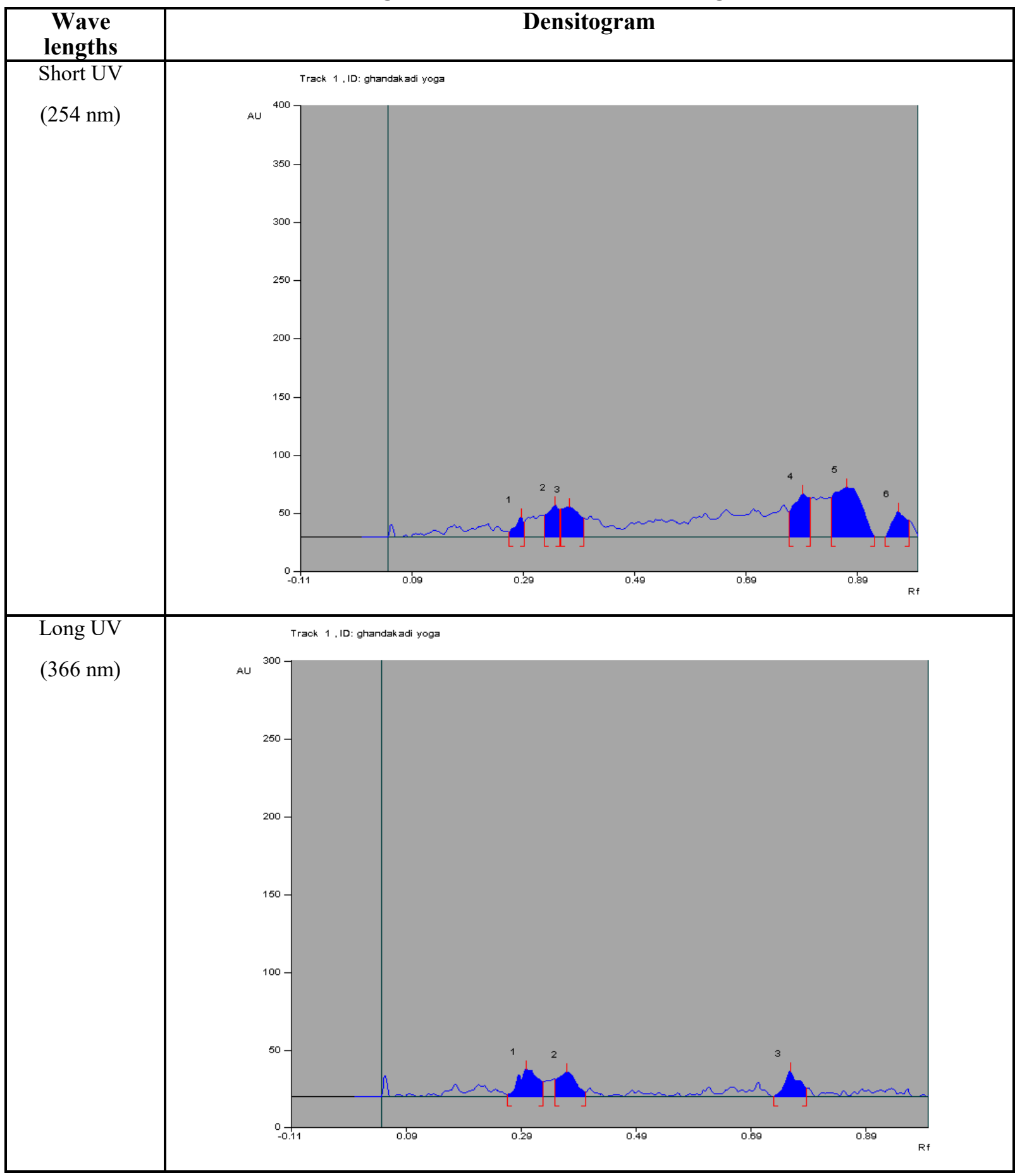




\section{Discussion}

Pharmacognostical study helps in authentication of the used drugs through morphological, histological and physico-chemical parameters. Therefore it can prevent the accidental misuse of drugs and adulteration when preparing any formulation. In the present study the formulation consist of three herbal ingredients which were proved to be genuine by assessing the pharmacognostical parameters. The therapeutic effect depends on the quality of the drug administered. To obtain the expected outcome after administration on particular disease, especially a combined drug formula all ingredients should be present in it. Pharmacognostical characteristic of Gandhakadi Yoga Vati under the microscope showed characters of all the ingredients of finished product and there is no major change in the microscopic structure of the raw drugs during the pharmaceutical processes of preparation of the drug. Evaluation of physico-chemical parameters and qualitative analysis helped to identify the presence of specific ingredients in a formulation and application of chromatographic techniques aid in recognition of number of ingredients and also to assess the purity by comparing with the standard ones.

\section{Conclusion}

Preliminary organoleptic characteristics and microscopic study of the Gandhakadi Yoga Vati showed that all ingredients used were genuine and all were found in the finished product too. Preliminary physicochemical parameters also are with in the standared range. Thus the study proves the quality of the final product.

\section{References}

1. Anonymous. The Ayurvedic Pharmacopoeia of India, Part 1, Vol. 1, 3, 4; 1st ed., New Delhi, Ministry of Health and Family welfare, Department of AYUSH, Govt. of India, 2008.

2. Trease and Evans, Pharmacognosy, $15^{\text {th }}$ Ed., W.B. Sunders Company Ltd. 1996, 569-570p.

3. Anonymous. The Ayurvedic Pharmacopoeia of India, Part 1, Vol. 1, 3, 4; 1st Ed., New Delhi, Ministry of Health and Family Welfare, Department of AYUSH, Govt. of India, 2008.

4. Anonymous, Indian Pharmacopoeia, Government of India, Ministry of Health and Family welfare, New Delhi, 1996, Volume II, 734p.

5. Ibidem, Indian Pharmacopoeia, 736p.

6. Ayurvedic Pharmacopoeia of India PDF-1, Govt. of India, Ministry of health and family welfare, Delhi, 2007, vol.-5, appendix-2.2.9., p. no. 214p.

7. Ibidem, Ayurvedic Pharmacopoeia of India, (1), $213 p$

8. Ibidem, Ayurvedic Pharmacopoeia of India, (1), Volume V, Appendix 2.2.4

9. Ibidem, Ayurvedic Pharmacopoeia of India, (1), $230 \mathrm{p}$.

10. Ibidem, Ayurvedic Pharmacopoeia of India, (1), $214 \mathrm{p}$.

11. Ibidem, Ayurvedic Pharmacopoeia of India, (1), $214 p$. 